\title{
Continuous retinoic acid induces the differentiation of mature regulatory monocytes but fails to induce regulatory dendritic cells
}

Zachary C VanGundy ${ }^{1}$, Mireia Guerau-de-Arellano ${ }^{2}$, Julie D Baker ${ }^{1}$, Heather R Strange ${ }^{1}$, Susan Olivo-Marston ${ }^{3}$, Dillon C Muth ${ }^{1}$ and Tracey L Papenfuss ${ }^{1 *}$

\begin{abstract}
Background: Myeloid cells (MC) have potent immunoregulatory abilities that can be therapeutically useful to treat inflammatory disease. However, the factors which promote regulatory myeloid cell differentiation remain poorly understood. We have previously shown that estriol (E3) induces mature regulatory dendritic cells in vivo. To determine whether additional steroid hormones could induce mature regulatory myeloid cells, we investigated the effects of retinoic acid (RA) on MCs. Retinoic acid is a steroid hormone important in regulating mucosal immunity in the gut and promoting myeloid differentiation. We hypothesized that the presence of RA during differentiation would promote the formation of mature regulatory myeloid cells ( $\left.M C_{\text {regs }}\right)$.

Methods: To determine RA's ability to induce regulatory myeloid cells, we differentiated bone marrow progenitor cells with granulocytic-macrophage colony-stimulating factor (GM-CSF) under the influence of RA. We found that day 7 MCs differentiated in the presence of RA had an increase in the percent positive and relative expression levels of both maturation (CD80, CD86, and MHCII) and inhibitory (PD-L1 and PD-L2) markers compared to control cells. Functionally, these day 7 RA MCs expressed increased intracellular IL-10, induced regulatory T cells in vitro compared to controls and suppressed the proliferation of responder immune cells even after inflammatory challenge with LPS.

Conclusion: RA induced mature regulatory myeloid cells that were suppressive and had a CD11 b $\mathrm{b}^{+} \mathrm{CD}_{11 \mathrm{c}^{-}}$ Ly6C low/intermediate monocyte phenotype. Surprisingly, RA CD11 $c^{+}$dendritic cells were not suppressive and could contribute to enhanced proliferation. These results suggest that continuous RA has unique effects on different myeloid populations during monopoeisis and dendropoiesis and promotes a population of regulatory monocytes.
\end{abstract}

Keywords: Regulatory myeloid cells, Dendritic cells, Retinoic acid, Monocyte

\section{Background}

Myeloid cells (MCs) are a diverse population of cells that form during hematopoiesis and play a critical role in host defense. Comprised of granulocytes, mononuclear phagocytes and their precursors, MCs are innate immune cells that have an important role in promoting inflammation and the induction of adaptive immune responses. Inflammatory MCs are induced and increased in numbers following exposure to exogenous (e.g. pathogens) or endogenous "danger" (e.g. post-necrotic release

\footnotetext{
* Correspondence: papenfuss.1@osu.edu

'Department of Veterinary Biosciences, The Ohio State University, College of Veterinary Medicine, 370 Veterinary Medical Academic Building, 1900 Coffey Road, Columbus, OH 43210, USA

Full list of author information is available at the end of the article
}

of high-mobility group box 1 or HMGB1) signals b [1]. These and other environmental factors present within peripheral tissue and bone marrow impact granulopoiesis, monopoiesis and dendropoiesis to influence the ultimate fate of inflammatory granulocytes, monocytes/ macrophages and DCs, respectively. While inflammatory MCs have been well characterized, within the last several years the potent regulatory abilities of these cells has increasingly been recognized. Such regulatory $\mathrm{MCs}\left(\mathrm{MC}_{\text {regs }}\right)$ are a diverse population of cells with the ability to control inflammation and, thus, are a promising target to treat a wide array of inflammatory diseases. To date, however, factors involved in the differentiation of $\mathrm{MC}_{\mathrm{reg}}$ populations remain poorly understood. 
$\mathrm{MC}_{\mathrm{reg}}$ subsets are particularly diverse, both in terminology and in function. Regulatory, tolerogenic, type II or steady-state are terms applied to regulatory populations of DCs, macrophages, monocytes, and their precursors [1-3]. By and large, the regulatory abilities of macrophages, and more recently, DCs have been most thoroughly studied. First described over 30 years ago, alternatively activated macrophages are able to promote wound healing and resolve inflammation $[4,5]$. Over the last 10 years the regulatory abilities of DCs and their therapeutic potential have been the focus of many studies $[2,6]$. Monocytes are circulating myeloid cells that give rise to tissue macrophages and DCs. Monocytes have been recognized as a contributor to the inflammatory responses, and are now known to contribute to immune regulation [7]. $\mathrm{MC}_{\text {regs }}$ can regulate immune responses through the production of soluble regulatory factors (e.g. IL-10, TGF-beta, indoleamine 2,3 deoxygenase (IDO), arginase, nitric oxide (NO), etc.), expression of inhibitory or regulatory cell surface molecules (e.g. PD-L1, PD-L2) and induction other regulatory cells (e.g. regulatory $\mathrm{T}$ cells; $\mathrm{T}_{\text {regs }}$ ) or enhance regulatory feed-back loops [8,9]. At present, $\mathrm{MC}_{\text {regs }}$ are identified based on combination of phenotype and function, with no equivalent to $\mathrm{T}_{\text {reg }}$ FoxP3 marker being as yet identified [10-13]. Through cell-cell interactions and the production of soluble immunoregulatory molecules, $\mathrm{MC}_{\text {regs }}$ have very potent and diverse means of inducing immune regulation. However, much remains to be characterized about factors controlling $\mathrm{MC}_{\mathrm{reg}}$ induction and how different $\mathrm{MC}_{\text {reg }}$ subsets regulate immune responses. Given that $\mathrm{MC}_{\mathrm{reg}}$ therapy has the potential to diminish disease in the $100+$ millions of individuals impacted by immune-mediated, chronic inflammatory and autoimmune diseases worldwide, it is critical to determine the factors which govern the induction and function of these cells [14-16]. The therapeutic potential of $\mathrm{MC}_{\mathrm{regs}}$, has been described in several experimental models of inflammatory and autoimmune disease. Specifically, $\mathrm{MC}_{\mathrm{regs}}$, including MDSC, conventional DCs, lung-resident tissue macrophages, monocytes, and plasmacytoid DCs have all been shown to impact disease course in animal models of diabetes [17], colitis [18], allergic asthma [19], experimental autoimmune disease [20], and rheumatoid arthritis [21] respectively.

For many $\mathrm{MC}_{\text {regs }}$, an arrest in immature and/or altered functionality contributes to their regulatory abilities [22,23]. Glucocorticoids, vitamin D and IL-10 are the most common means to induce these immature $\mathrm{MC}_{\text {regs. }}$ These altered $\mathrm{MC}_{\text {regs }}$ cells have decreased expression levels of maturation/activation markers CD80, CD86 and MHC class II [2,24-28]. Additionally, these immature $\mathrm{MC}_{\text {regs }}$ can have reduced inflammatory cytokine expression $[29,30]$, overall blunted function, induce $T_{\text {regs }}$ and suppress the action of other immune cells. However, a primary concern with using immature $\mathrm{MC}_{\mathrm{regs}}$ for therapy is that they may mature into inflammatory MCs under inflammatory disease conditions. Such inflammatory MCs could then actually exacerbate the very inflammatory disease they were used to treat [2,22,23,31]. Thus, mature (and stable) $\mathrm{MC}_{\text {regs }}$ may avoid such concerns but, to date only a handful of studies have significantly explored the induction of such mature $\mathrm{MC}_{\text {regs }}$ $[18,22,32]$. Typically, mature $M_{\text {regs }}$ have been induced by combining traditional immature $\mathrm{MC}_{\mathrm{reg}}$ induction protocols with the addition of inflammatory stimuli such as LPS or TNF-alpha [33,34]. Our laboratory has focused on identifying non-inflammatory systems to induce mature $M C_{\text {regs }}$ and we have previously found that estriol (E3), a steroid hormone of pregnancy, produce mature activated $\mathrm{DC}_{\mathrm{regs}}$ [35]. These E3 $\mathrm{DC}_{\mathrm{regs}}$ maintained their regulatory abilities within an inflammatory environment and protected mice against the inflammatory autoimmune disease, experimental autoimmune encephalomyelitis (EAE) [35]. Although E3 shows promise, the fact that there are limitations on using estrogens broadly in the human patient population necessitated investigating alternative means of inducing mature stable $\mathrm{MC}_{\text {reg }}$ populations.

All-trans retinoic acid (RA) is a steroid hormone metabolite of vitamin A that plays both an important role during embryonic development and has recently been identified as the key metabolite regulating immune responses at mucosal sites [36-38]. RA is a logical candidate for inducing mature $\mathrm{MC}_{\text {regs }}$ given its defined role in both mucosal immunoregulation and its ability to promote myeloid cell differentiation and maturation. Within the gut, RA influences the balance between $\mathrm{T}_{\text {regs }}$ and Th17 cells, B cell isotype switching, antibody production and mucosal homing of numerous immune cells [6,37,39-43]. Mucosal myeloid cells are largely responsible for producing local RA which acts in a paracrine and autocrine manner to regulate mucosal immune responses [6,37]. Although mucosal DCs produce much of the RA required for immune regulation at mucosal sites, much less is known about RA's direct impact on MC populations at both mucosal and nonmucosal sites $[9,19,39,40]$.

RA regulates myeloid cell survival and promotes the differentiation of immature myeloid cells into mature populations of DCs, macrophages and granulocytes [18,44-46]. Additionally, RA appears to be required for the production of mature phagocytes in the bone marrow through its effects on MHC class II and co-stimulatory molecule expression [47]. Therapeutically, RA has long been used to treat myeloid leukemia given that it promotes myeloid cell differentiation and maturation [48,49]. More recently, it has been used to promote the differentiation of immature myeloid cells (i.e. myeloid derived suppressor cells; MDSCs) in cancer patients to diminish immunosuppressive MDSC effects 
[36,44,50-53]. Given RA's important roles in both mucosal immunoregulation and myeloid cell differentiation we hypothesized that RA would induce mature $\mathrm{MC}_{\text {regs }}$.

Using an in vitro model to induce differentiation of MC populations (i.e. DCs, macrophages and monocytes), we evaluated the ability of RA to generate mature $\mathrm{MC}_{\text {regs }}[42,54]$. We demonstrated that bone marrow cells differentiated with GM-CSF for 7 days in the presence of RA had an activated regulatory phenotype (i.e. increased CD80, CD86, MHC class II, PD-L1 and PDL2), produced increased IL-10, increased the induction of $\mathrm{T}_{\text {reg }}$ and suppressed the proliferation of responder immune cells. We found that the suppressive population was a small but potent $\mathrm{CD}_{11 \mathrm{~b}^{+}} \mathrm{CD} 11 \mathrm{c}^{-}$Ly6 $\mathrm{C}^{\text {low/intermediate }}$ population whose phenotype is consistent with a regulatory monocyte. Surprisingly the CD11c ${ }^{+}$DCs were not suppressive. Taken together these results demonstrate a differential effect of RA during monopoiesis and dendropoiesis which results in the induction of regulatory monocytes but not regulatory DCs.

\section{Results \\ Differentiation with retinoic acid induced mature activated regulatory myeloid cells}

Given that RA is a regulator of mucosal immunity and influences myelopoiesis, we hypothesized that RA would induce a population of mature $\mathrm{MC}_{\text {regs }}$. Day 6-7 BM cells differentiated with GM-CSF in the presence of RA were able to suppress the proliferation of responder immune cells and this suppression was markedly greater than either control or E3 treated cells (Figure 1A). The ability of RA differentiated cells to suppress proliferation was apparent regardless of whether responder immune cells were stimulated with either peptide or anti-CD3. Interestingly, cells treated with E3 suppressed proliferation after stimulation with peptide but not anti-CD3 (Figure 1A). We next determined whether the RA differentiated cells remained regulatory when exposed to the inflammatory stimulus LPS. Figure 1B shows that RA differentiated cells maintained their ability to suppress proliferation even after exposure to LPS challenge and that this was present following stimulation of co-cultures with either peptide or anti-CD3. This effect was entirely lost in E3 treated cells. These results suggest that RA differentiated cells are more potent and stable than E3 differentiated cells and that RA differentiated cells maintain their regulatory ability following exposure to an inflammatory stimulus.

Given that increased IL-10 is seen in E3 DC $\mathrm{Drgs}_{\text {[35] }}$ and other $\mathrm{MC}_{\text {reg }}$ populations [50,55] we next evaluated whether RA induced an increase number of $\mathrm{IL}-10^{+}$cells. Figure $1 \mathrm{C}$ shows that RA differentiated cells had an increased percentage of IL-10-producing cells compared to either media or E3 control cells. We next evaluated whether RA differentiated cells could increase $T_{\text {reg }}$ numbers. We found that RA differentiated cells were able to induce a significant increased percentage of FoxP3 $^{+}$cells following a 5 day culture with naive immune cells (Figure 1D). Cells differentiated in vitro in the presence of E3 failed to significantly increase either IL- $10^{+}$cells or induce $\mathrm{T}_{\text {reg }}$ cells (Figures $1 \mathrm{C}, \mathrm{D}$ ). These results show that RA differentiated cells suppressed the proliferative abilities of responder immune cells and induced FoxP3 ${ }^{+}\left(\mathrm{T}_{\text {reg }}\right)$ cells.

To determine whether these RA differentiated cells were mature, we evaluated the cell surface expression of maturation markers CD80, CD86 and MHC class II and inhibitory markers PD-L1 and PD-L2. RA differentiated cells demonstrated an increased percentage of $\mathrm{CD}^{+} 0^{+}$, $\mathrm{CD}^{+} 6^{+}$and $\mathrm{MHC}$ class $\mathrm{II}^{+}$(Figure 2A), indicating that an increased proportion of the cells were mature and/or activated in comparison to E3 or control cells. Additionally, there were increases in the mean fluorescence intensity (MFI) of CD80, CD86 and MHC class II in RA differentiated cells as depicted in Figures $2 \mathrm{C}$ and $\mathrm{D}$, indicating that the relative expression levels on a per cell basis were increased in RA differentiated cells. Although E3 differentiated cells had mildly increased expression levels of CD80, CD86 and MHC class II, RA differentiated cells had consistently higher levels than either E3 differentiated or control cells. To confirm that RA differentiated cells demonstrated an "activated regulatory" phenotype as previously described for E3, we evaluated the expression of inhibitory co-stimulatory molecules PD-L1 and PD-L2 [35]. RA increased the percentage of PD-L1 ${ }^{+}$cells (but not PD-L2 ${ }^{+}$) (Figure 2B) and the MFI of both PD-L1 and PD-L2 (Figure 2C, D) compared to E3 or media controls. These results demonstrate that during differentiation RA induces a population of mature activated $\mathrm{MC}_{\mathrm{regs}}$ that suppress the proliferation of responder immune cells even in the face of inflammatory challenge. Additionally, our data shows that although both $\mathrm{RA}$ and $\mathrm{E} 3$ may induce $\mathrm{MC}_{\text {regs }}$ which suppress proliferation (Figure 1A) RA $M_{\text {regs }}$ appear to have superior regulatory abilities compared to $\mathrm{E} 3 \mathrm{MC}_{\text {regs }}$.

\section{CD11 $\mathrm{b}^{+}$but not $\mathrm{CD} 11 \mathrm{c}^{+}$cells were the suppressive population}

The in vitro differentiation of bone marrow cells with GM-CSF is a commonly used protocol to produce large numbers $(>80 \%)$ of highly enriched CD11c ${ }^{+}$DCs $[38,56]$ that, as a population, are considered immature DCs. However, our data demonstrated that while approximately $80-90 \%$ of the cells were $\mathrm{CD} 11 \mathrm{c}^{+}$, the remaining 10-20\% were CD11 $\mathrm{c}^{-}$but still CD11b ${ }^{+}$(Additional file 1: Figure S1A). To determine whether the $\mathrm{MC}_{\text {regs }}$ induced by RA were DCs, we purified CD11c ${ }^{+}$cells from day 7 differentiated cells and cultured them with responder 


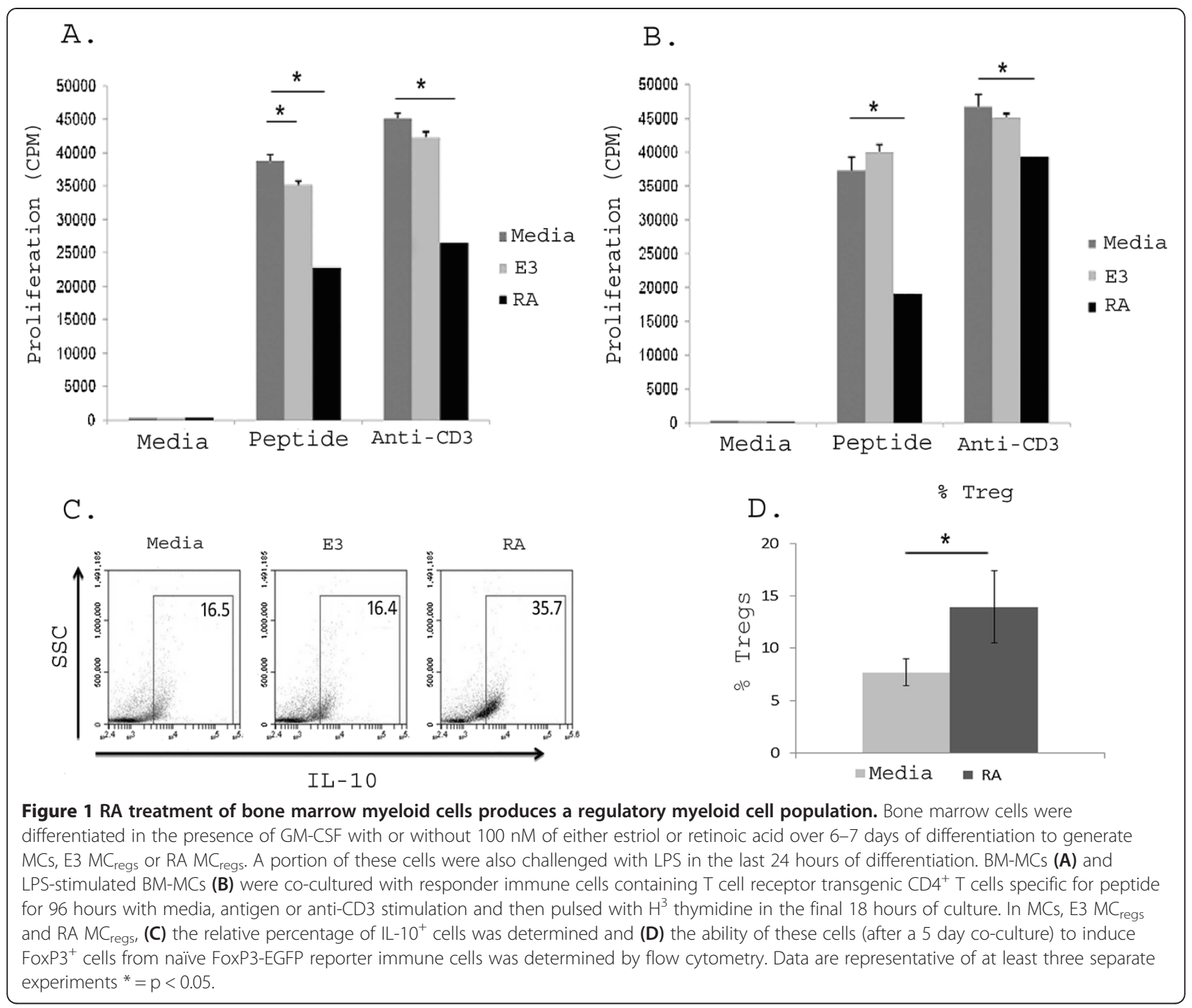

immune cells. Although RA induction of mucosal " $D C_{\text {regs }}$ " have been described $[9,36,57]$, we found that RA-treated CD11c ${ }^{+}$cells were not the suppressive cell population (Figure $3 \mathrm{~A}$ ). In all experiments, RA-treated CD $11 \mathrm{c}^{+}$cells failed to suppress proliferation and had variable to no effect on proliferation with some experiments actually demonstrating enhanced proliferation (data not shown). Phenotypic evaluation of these $\mathrm{CD}_{11 \mathrm{c}^{+}}$cells showed no difference in percentage (Figure 3B) or expression levels of CD80, CD86, MHC class II, PD-L1 and PD-L2 compared to media controls. To determine the source of the suppressive $\mathrm{MC}_{\text {regs }}$, we evaluated the CD11 ${ }^{-}$population and found that the RA CD11c cells suppressed proliferation of responder cells (Figure $3 \mathrm{C}$ ). These CD11 $\mathrm{c}^{-}$cells had a marked $(>30 \%)$ increase in the percentage of $\mathrm{CD}^{+}, \mathrm{CD}^{+} 6^{+}$, MHC class $\mathrm{II}^{+}$and PD-L1 ${ }^{+}$cells (with no differences in
PD-L2 ${ }^{+}$cells) (Figure 3D) when differentiated with RA, consistent with an activated regulatory phenotype in these cells described previously [35]. In contrast, levels of CD80, MHC class II and PD-L1 did not change, remaining consistently high $(>80 \%)$ in RA versus control MCs. (Figure 3B). These data suggest that RA present during GM-CSF differentiation increased an activated regulatory phenotype in the CD11c (non-DC) populations.

Both differentiated and precursor populations within the bone marrow are predominantly but not completely $\mathrm{CD}_{11 b^{+}}$(>90\%) (Additional file 1: Figure S1A). To de-

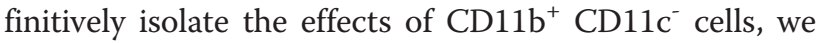
serially purified $\mathrm{CD} 11 \mathrm{~b}^{+}$cells from the $\mathrm{CD} 11 \mathrm{c}^{-}$fraction and evaluated their phenotype and function. As expected, the increases in the percentage of $\mathrm{CD}^{+} 0^{+} \mathrm{CD}^{+} 6^{+}, \mathrm{MHC}$ class $\mathrm{II}^{+}$and PD- $\mathrm{L}^{+}$cells seen in Figure 3D was also

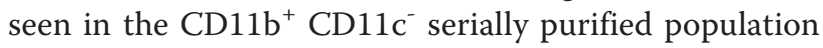




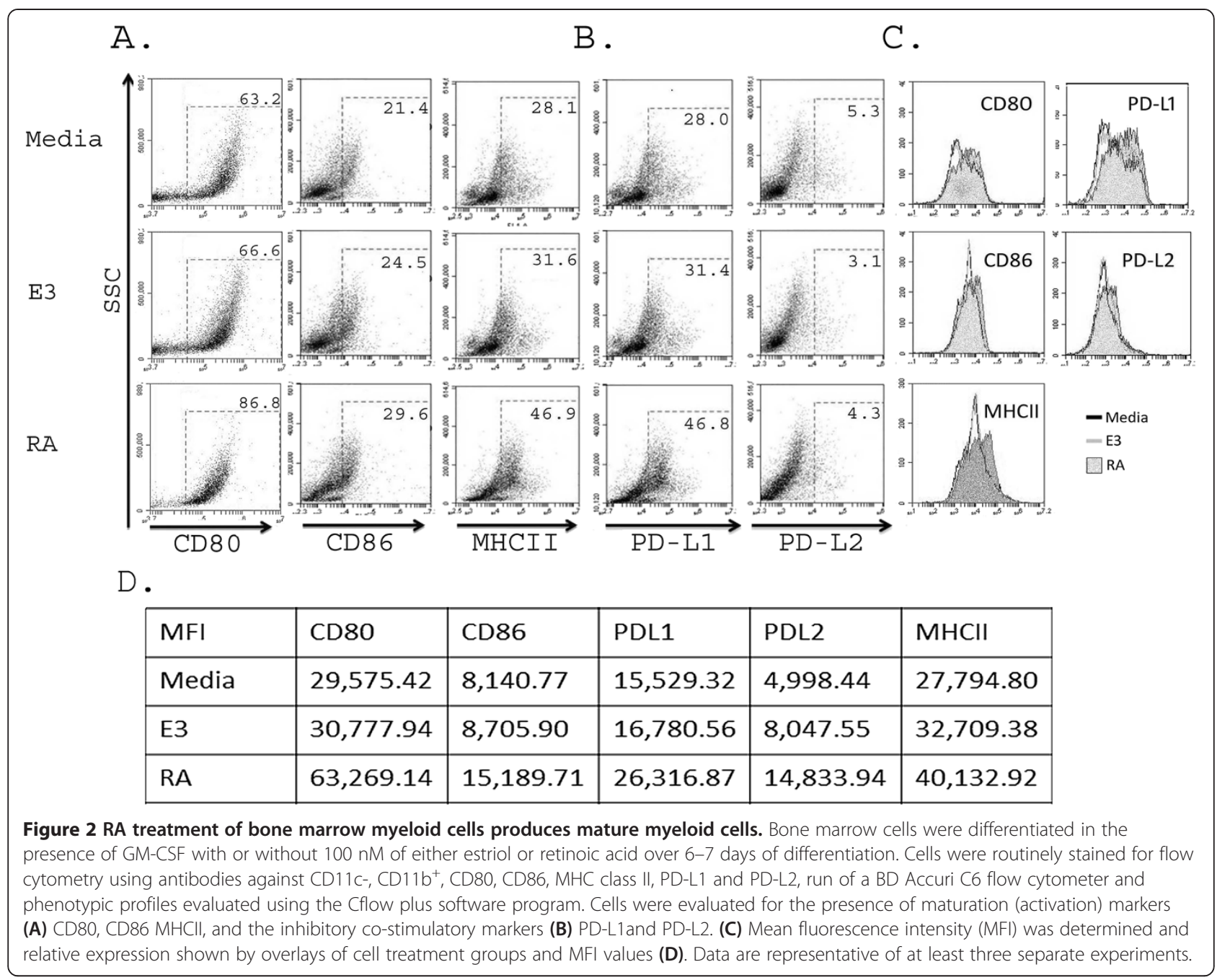

(Figure 4A). We then went on to evaluate the ability of these cells to influence CD4 and CD8 responses. We found that the $\mathrm{CD}_{11} \mathrm{~b}^{+} \mathrm{CD} 11 \mathrm{c}^{-}$population was able to suppress the proliferation of responder immune cells (Figure 4B) and could modify the cytokine profile of $\mathrm{T}$ cells. The proliferating $\mathrm{CD}_{4}^{+}$responder immune cells cultured with RA CD11 $\mathrm{b}^{+} \mathrm{CD} 11 \mathrm{c}^{-}$cells were also shown to have reduced expression of IL-17 IFN-gamma (Figure 4C) and IL-10 (Additional file 2: Figure S2) but no change in IL-4 production as determined by intracellular cytokine staining (Figure 4C). Intracellular IL-10 and $\mathrm{FoxP}^{+}$cells were also increased as expected (Additional file 2: Figure S2A and S2B, respectively). We also evaluated the ability of RA CD $11 b^{+}$CD11 $\mathrm{c}^{-}$ cells to influence $\mathrm{CD}^{+} \mathrm{T}$ cell responses. Figure 4D demonstrates reduced cytotoxicity in $\mathrm{CD}^{+} \mathrm{T}$ cells cultured with RA CD11 $\mathrm{b}^{+} \mathrm{CD} 11 \mathrm{c}^{-}$cells. Taken together, these results suggest that RA induced an activated regulatory

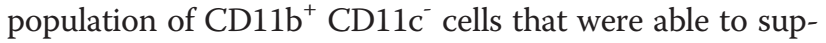
press both $\mathrm{CD} 4^{+}$and $\mathrm{CD} 8^{+}$adaptive immune responses.

\section{$\mathrm{CD}_{11 b^{+} \text {CD11c-Ly6C low/intermediate }}$ were the primary} population responsible for suppression

Although used primarily to induce large numbers of DCs, differentiation with GM-CSF can potentially promote the differentiation of a mixture of granulocytes, monocytes, macrophages and DCs [42,54,56,58-60] In our GM-CSF cultures, we found that Ly- $6 \mathrm{G}^{+}$granulocytes were no longer present in $\mathrm{CD}_{11} \mathrm{~b}^{+}$cells at day 7 of differentiation (Additional file 1: Figure S1B), indicating that granulocytes were not responsible for the suppression seen [61,62]. To determine whether monocytes were present and may be responsible for the suppressive effects, we evaluated day 7 non-adherent cells sorted based on their relative expression of the monocyte marker Ly-6C. Ly-6C expression levels have been shown to correlate with cellular function and maturation level where Ly- $6 C^{\text {high }}$ monocytes are inflammatory and Ly$6 C^{\text {low }}$ monocytes are steady-state or regulatory $[7,63]$. Figure 5A shows that the presence of RA during differentiation increased the percentage of cells expressing 


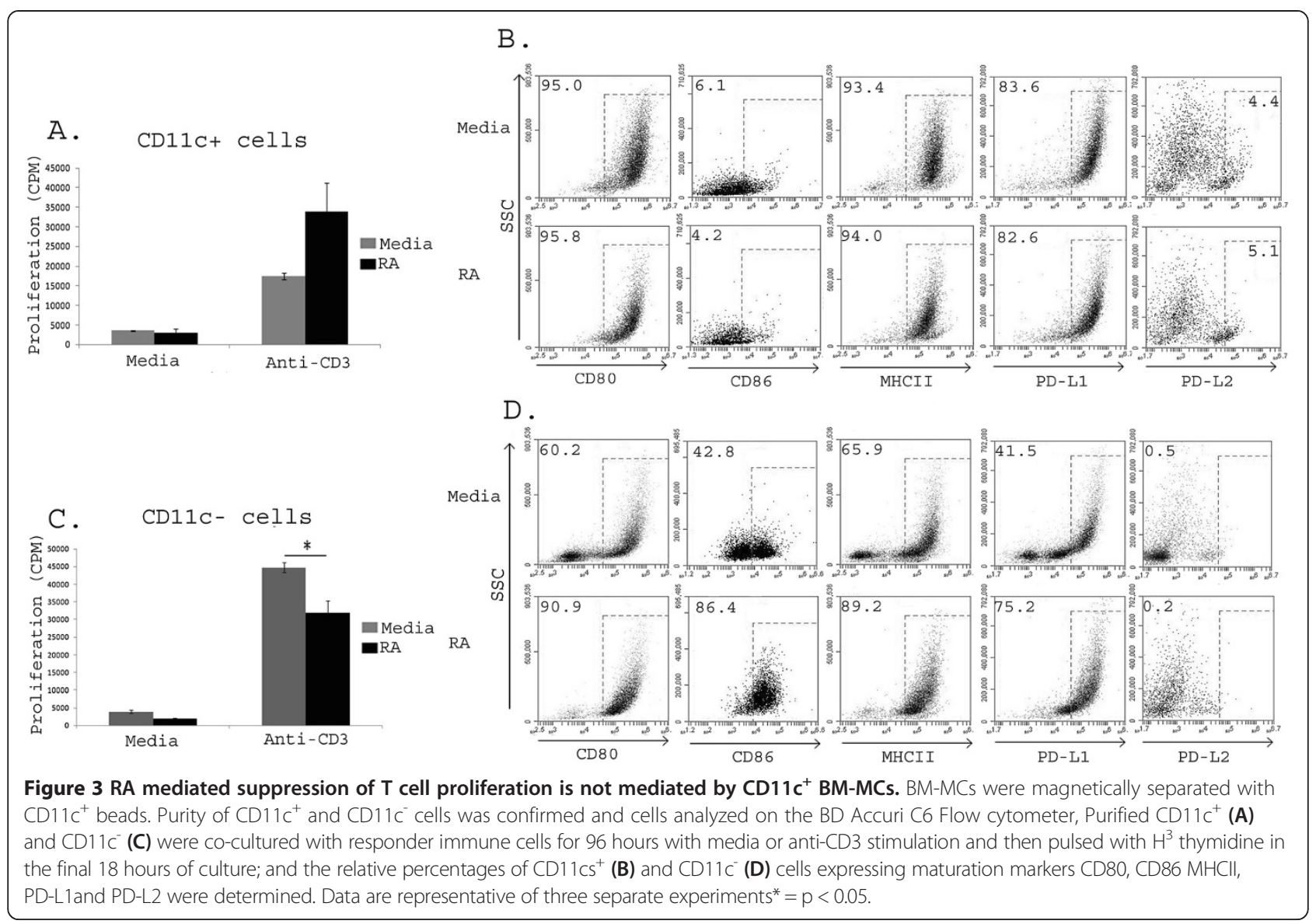

low to intermediate levels of Ly6C. To determine whether the increase in these cells was responsible for the suppression seen in the $\mathrm{CD} 11 \mathrm{~b}^{+} \mathrm{CD} 11 \mathrm{c}^{-}$population, we sorted cells based on Ly- $6 C^{\text {low }}, \mathrm{Ly}-6 \mathrm{C}^{\text {intermediate }}$, and Ly- $6 C^{\text {high }}$ expression patterns. Figure $5 \mathrm{~B}$ demonstrates that both $\mathrm{Ly}-6 \mathrm{C}^{\text {low }}$ and Ly- $6 \mathrm{C}^{\text {intermediate }}$ cells were able to suppress up to a 6 -fold decrease in proliferation of responder cells following antigenic stimulation while Ly- $6 C^{\text {high }}$ cells failed to influence peptide-specific proliferation. Similarly, Ly-6C ${ }^{\text {low }}$, Ly- $6 C^{\text {intermediate }}$ cells maintained their ability to suppress proliferation (Figure $5 \mathrm{C}$ ) even when co-cultures were stimulated with LPS. In contrast, Ly- $6 C^{\text {high }}$ actually significantly increased the proliferation of responder immune cells (Figure 5C) following stimulation with LPS. These results demonstrate that RA Ly- $6 \mathrm{C}^{\text {low }}$ and Ly- $6 \mathrm{C}^{\text {intermediate }}$ cells are the suppressive population and are able to maintain suppressive abilities even in the presence of inflammatory (LPS) challenge. Phenotypically, RA Ly- $6 C^{\text {low }}$ cells showed the most marked increase in the percentage of $\mathrm{PD}-\mathrm{L}^{+}$, as well as, $\mathrm{CD}^{+} 6^{+}$and $\mathrm{MHC}$ class $\mathrm{II}^{+}$cells, with over $90 \%$ of the Ly-6C ${ }^{\text {low }}$ cells expressing PD-L1 (Figure 6). A similar but less dramatic phenotype was seen in the Ly$6 C^{\text {intermediate }}$ cells (data not shown). Taken together, these data show that RA induces a small but potent population of $\mathrm{CD}_{11 \mathrm{~b}^{+}} \mathrm{CD}_{11 \mathrm{c}^{-}}$Ly-6C $\mathrm{C}^{\text {low/intermediate }}$ $\mathrm{MC}_{\text {regs }}$ consistent with an activated regulatory monocyte phenotype that are able to suppress immune cell proliferation.

\section{Discussion}

The principal objective of this study was to determine whether RA, a steroid hormone known to play important roles in regulating both mucosal immune responses and differentiation of myeloid cells could generate an activated (or mature) $\mathrm{MC}_{\text {reg }}$ population. We demonstrate that RA influences myelopoiesis to a regulatory $\mathrm{MC}_{\text {reg }}$ (monocyte) with the phenotype of CD11b ${ }^{+}$CD11c-Ly$6 \mathrm{C}^{\text {low/intermediate }}$ but fails to induce $\mathrm{DC}_{\text {regs. }}$. These cells can influence both $\mathrm{CD}_{4}^{+}$and $\mathrm{CD}^{+}$responses and promote FoxP3 ${ }^{+}\left(\mathrm{T}_{\text {reg }}\right)$ cell induction. Our data suggest that RA has distinctly different effects on monopoiesis and dendropoiesis to promote the generation of regulatory monocytes.

$\mathrm{MC}_{\mathrm{regs}}$ are a diverse population of cells and much attention has focused on the in vitro generation and clinical application of $\mathrm{MC}_{\text {regs. }}$. While the in vitro generation of such $\mathrm{MC}_{\mathrm{reg}}$ populations has great therapeutic 


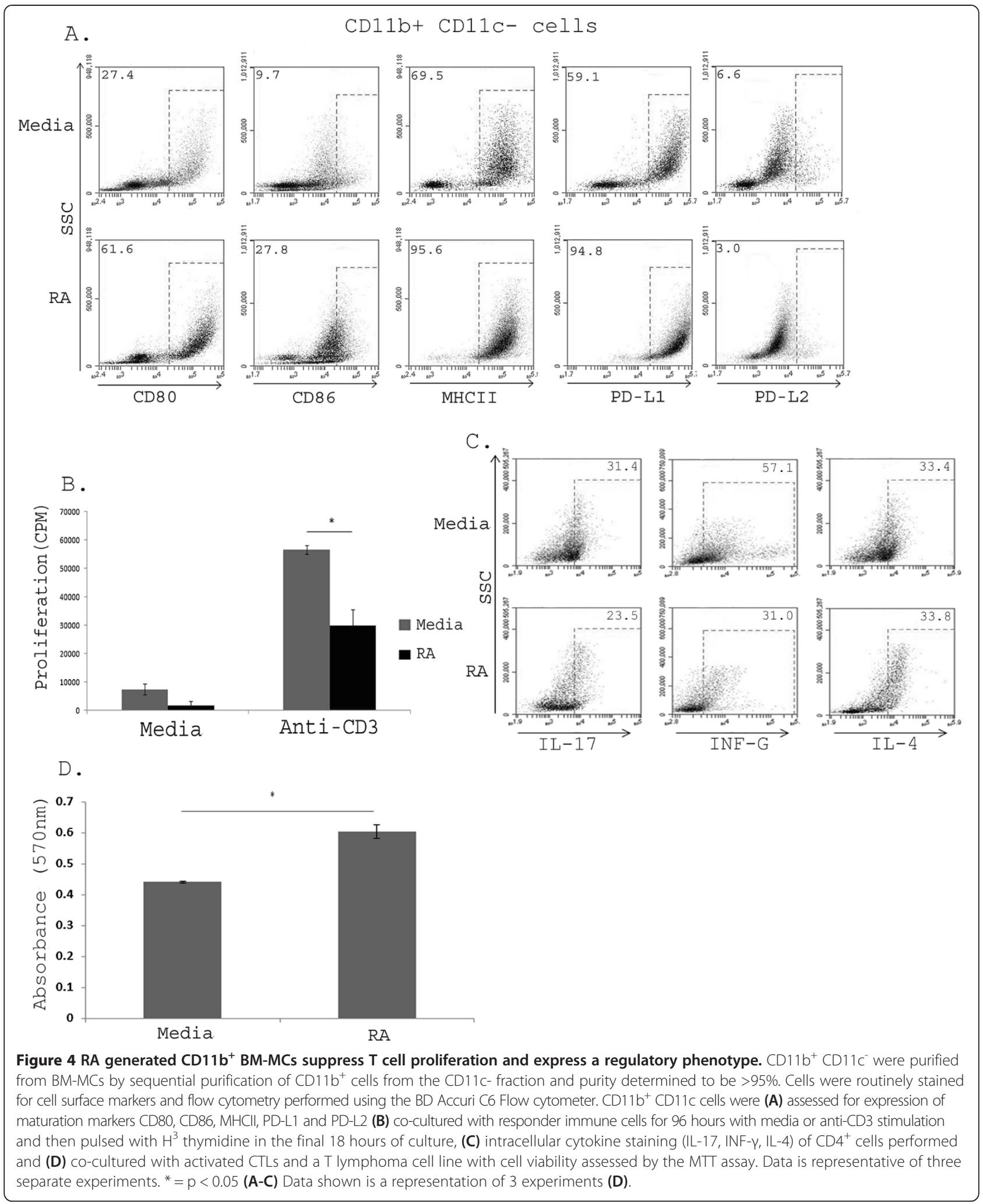

potential, much remains to be learned regarding the factors which contribute to $\mathrm{MC}_{\text {reg }}$ induction. The majority of in vitro generated $\mathrm{MC}_{\text {regs }}$ are arrested in an immature or hypo-functional state. An emerging concern is that these immature $\mathrm{MC}_{\text {regs }}$ populations may mature to become inflammatory DCs or macrophages and, thus, contribute to 

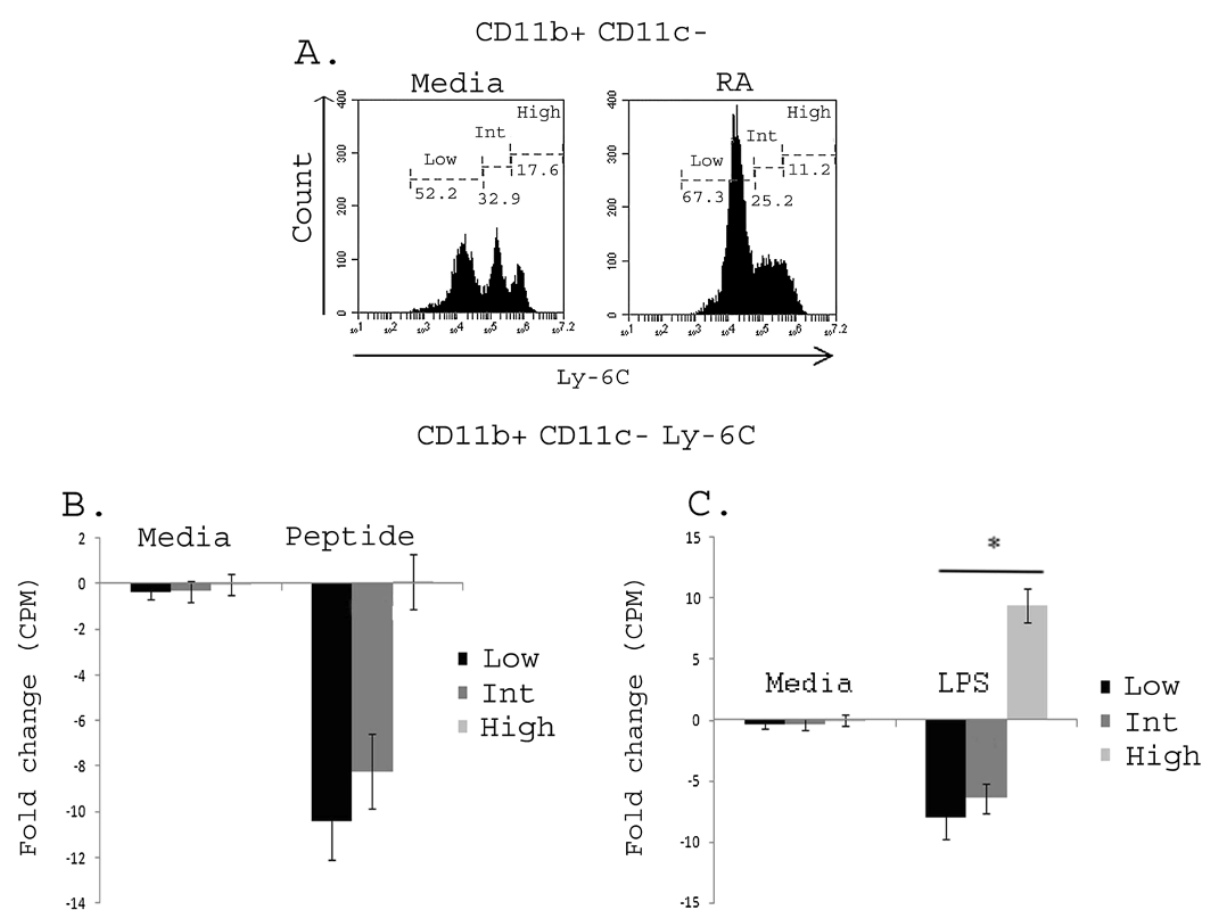

Figure 5 RA CD11 b ${ }^{+}$CD11c-Ly6C $C^{\text {low/intermediate }}$ are the suppressive population. BM cells were differentiated in the presence of GM-CSF with or without $100 \mathrm{nM}$ RA for 7 days, stained with fluorescently-labeled antibodies against CD11C, CD11 $\mathrm{b}^{+}$, and Ly-6C to determine relative expression of Ly6C on CD11 b+ CD11c cells (A). Cells were then sorted based on relative Ly6C expression and purified populations co-cultured with antigen-specific T cell receptor transgenic T cells for 96 hours with media, peptide or LPS and fold change in proliferation shown for peptide-stimulated (B) or LPS-stimulated (C) co-cultures. Data are representative of at least three separate experiments. ${ }^{*}=p<0.05$.

inflammatory disease pathology [2,22,23,29-31,64]. A more recent approach is to induce mature $\mathrm{MC}_{\text {regs }}$ which would be stable and maintain regulatory potential in an inflammatory environment $[22,32,65,66]$. Anderson and colleagues have demonstrated that human $\mathrm{DC}_{\text {regs }}$ (generated with dexamethasone, vitamin D and LPS) maintain tolerogenic activity and actually induce significantly higher levels of IL-10 production by resultant $\mathrm{T}$ cells [33]. However, the relative stability and ability of $\mathrm{MC}_{\text {regs }}$ (such as $\mathrm{DC}_{\text {regs }}$ ) to maintain regulatory abilities during inflammation may still be in question. For example, a study by Voigtlander et al. suggests that $\mathrm{DC}_{\text {regs }}$ induced by TNF-alpha do not maintain their regulatory abilities upon a secondary stimulation with TNF-alpha in vivo [34]. Obviously, this is of considerable concern given that TNF-alpha is present in a large array of inflammatory conditions where such $\mathrm{DC}_{\text {regs }}$ (or other $\mathrm{MC}_{\text {reg }}$ populations) may be applied therapeutically. Much work remains to determine critical factors important in generating mature $\mathrm{MC}_{\text {regs }}$ for anti-inflammatory therapies but we have focused on non-inflammatory pathways to induce mature $\mathrm{MC}_{\text {regs }}$.

We have shown that mature $\mathrm{MC}_{\text {regs }}$ can be generated with the use of steroid hormones alone [35]. Our previous work has shown that the sex steroid hormone estriol (E3) induces a mature activated $\mathrm{MC}_{\mathrm{reg}}$ population of $\mathrm{CD} 11 \mathrm{c}^{+}$
$\mathrm{DC}_{\mathrm{regs}}$ that protects against inflammatory challenge in vitro and in an in vivo disease model [35]. In the present study, we have extended our research of pathways involved in normal homeostatic induction of mature $\mathrm{MC}_{\text {regs }}$ by investigating the ability of the steroid hormone $\mathrm{RA}$ to induce mature $\mathrm{MC}_{\text {regs }}$ that are resistant to inflammatory challenge. Our results show that RA is more effective than $\mathrm{E} 3$ in vitro in generating $\mathrm{MC}_{\mathrm{regs}}$ and that these $\mathrm{MC}_{\text {regs }}$ are resistant to LPS inflammatory challenge.

RA is known for its ability to promote the differentiation, and maturation, of myeloid cell populations. This ability, along with its known immunoregulatory role at mucosal sites, made it a logical candidate for these studies $[44,52]$. RA is present in relatively large concentrations within mucosal sites and is largely produced by local antigen presenting cells (APCs) residing within these mucosal sites. Specifically, mucosal $\mathrm{CD}_{103}{ }^{+} \mathrm{DCs}$ are the primary immunoregulatory myeloid cells within the gut. These DCs have up-regulated raldh2 gene expression, constitutively produce RA, and produce increased TGF-beta. They also have a significant ability to induce Foxp $3^{+} \mathrm{T}_{\text {regs }}$, mucosal homing receptors CCR 9 and $\alpha 4 \beta 7$ expression on lymphocytes and enhance antibody production and Ig isotype switching $[6,9,36,57]$. These mucosal DCs are the most common MCs investigated regarding RA biology and induced mucosal DCs have been generated from monocytes 


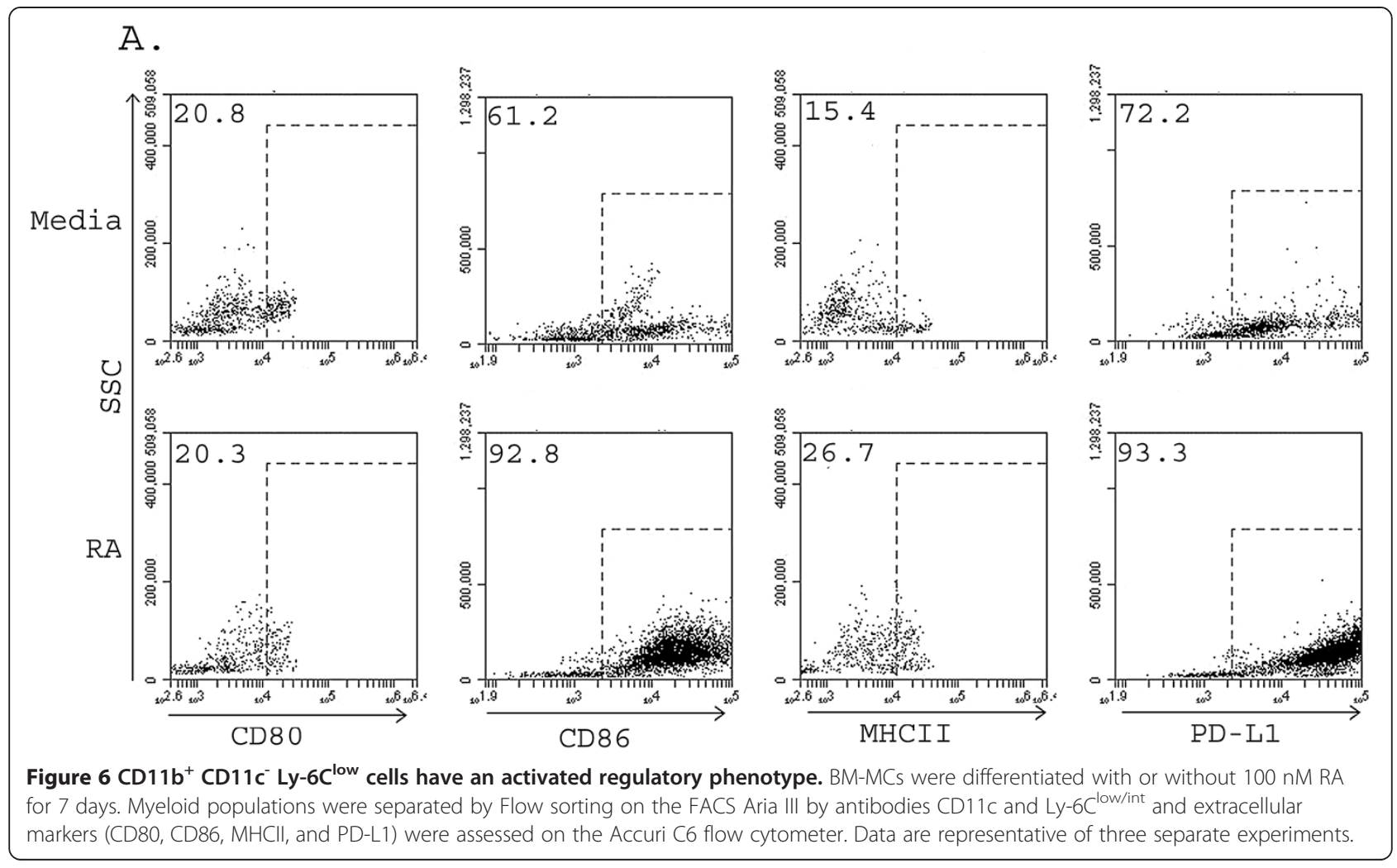

or splenic DCs with GM-CSF with IL-4 $[8,43]$ or bone marrow precursors with RA $[18,41,57,67,68]$. Increasingly, the non-mucosal and therapeutic applications of RA (i.e. in cancer) are being investigated $[9,19,43,44,53]$ and this study focused on RA's ability to induce mature activated $M_{\text {regs }}$ that are able to suppress responder immune cell proliferation $[8,35,41,43,57,69]$.

Given RA's critical role in DC-mediated immunoregulation within the gut, it was quite surprising that RA $\mathrm{CD}_{11 \mathrm{c}^{+}}$cells were not suppressive. One possibility is that DC's differentiated with RA could generate mucosal DCs but wouldn't generate mature activated $\mathrm{DC}_{\text {regs }}$ that could suppress proliferation as seen with $\mathrm{E} 3 \mathrm{DC}_{\text {regs. }}$ While induction of mucosal DCs can be accomplished with RA $[18,43]$, the immunomodulatory abilities of these DCs as described in these studies was not the focus of this study. Alternatively, timing of RA administration may have resulted in the lack of $\mathrm{DC}_{\text {reg }}$ induction as described by Feng and colleagues [41]. Specifically, their studies showed that the presence of $1 \mu \mathrm{M}$ RA from day 0 throughout differentiation failed to induce mucosal DCs. Although different dosages and criteria were used to generate and identify DCs as mucosal (versus $\mathrm{DC}_{\text {regs }}$ in our study), the continuous presence of RA during differentiation may have resulted in the inability to induce $\mathrm{DC}_{\text {regs }}$ in our study. Similarly, Wada's group showed that the use of a synthetic RAR $\alpha$ and $\beta$ agonist (AM-80) could differentiate human peripheral blood monocytes into dendritic cells that have a tolerogenic phenotype and function [18]. The use of AM-80 versus ATRA in our study or the differentiation of human monocytes versus murine myeloid progenitors could explain the differences in $\mathrm{DC}_{\text {regs }}$ versus $\mathrm{MC}_{\text {regs }}$ in our study.

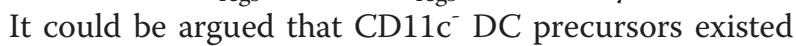
within the population of $\mathrm{CD}_{11 \mathrm{~b}^{+}} \mathrm{CD} 11 \mathrm{c}^{-}$suppressive cells. Given the described effects of RA in promoting differentiation and maturation, in conjunction with our data demonstrating an activated phenotype, we believe this to be unlikely [57,70-72]. Rather, our data on Ly6C expression strongly support that the suppressive cells were regulatory monocytes with an activated regulatory phenotype (increased CD80, CD86, MHC class II and PD-L1) consistent with previous work within our lab. Given that the CD11b $\mathrm{b}^{+} \mathrm{CD} 11 \mathrm{c}^{-}$population is comprised less than $20 \%$ of the entire population, the ability of these cells to suppress both $\mathrm{CD} 4^{+}$and $\mathrm{CD} 8^{+}$responses is noteworthy. The specific contributions of cell contactdependent (i.e. PD-L1) versus cell contact-independent (i.e. IL-10, TGF-beta, etc.) mechanisms responsible for the regulatory abilities of these cells was beyond the scope of this study. However, we did see increases in regulatory markers including PD-L1, IL-10 and the percentage of FoxP3 ${ }^{+}$cells with RA $\mathrm{MC}_{\text {regs }}$.

Monocytes are circulating myeloid cells which give rise to tissue DCs and macrophages, and their regulatory abilities have recently been recognized [7]. Although numerous markers can be present on mouse monocytes (e.g. 
CD11b, CD115, CCR2, CX3CR1 and Ly-6C), we chose to investigate Ly6C expression levels given that they have been correlated with monocyte function $[7,63,71,73]$. Specifically, Ly-6C ${ }^{\text {high }}$ represents an inflammatory monocytes while, Ly-6C ${ }^{\text {low/intermediate }}$ monocytes have been shown to play important roles in patrolling the vasculature and potentially resolving inflammation and tissue repair [7,63,74-76]. Ly6C is also down regulated following differentiation which is consistent with our findings where RA, a molecule known to promote differentiation and maturation, increases the percentage of cells that are Ly- $6 C^{\text {low/ }}$ intermediate (Figure 5A) [3,44]. Our data suggest that Ly-6C levels correlate with suppressive abilities with the lowest Ly-6C expression associated with the most suppressive ability. Given that Ly-6C ${ }^{\text {high }}$ monocytes are typically inflammatory monocytes, it is not surprising that proliferation is actually enhanced following LPS stimulation in this cell population (Figure 5C). Taken together, these data showed a progression from Ly- $6 C^{\text {high }}$ to Ly- $6 C^{\text {low }}$ associated with increasing regulatory abilities. These results are consistent with the association seen between Ly-6C expression and blood monocyte function described by others $[7,63,71,77]$. Currently, the mechanisms and pathways by which RA maturation of monocytes imparts them with increased regulatory abilities remain undefined. Whether a specific signal during differentiation drives monocytes to become regulatory in an active process or whether differentiation under homeostatic or regulatory (i.e. RA) conditions in the absence of inflammatory stimuli is a default mechanism for regulatory monocyte induction is unknown. Additionally, whether these RA Ly- $6 C^{\text {low/intermedi- }}$ ate monocytes have the potential to further differentiate into $\mathrm{DC}_{\mathrm{reg}}$ or regulatory macrophage populations remains to be determined and is the subject of ongoing studies within the laboratory [7].

\section{Conclusion}

Our findings show that continuous RA exposure during myelopoiesis promotes the induction of $\mathrm{MC}_{\text {regs }}$. Specific-

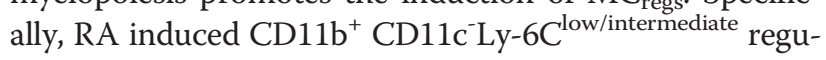
latory monocytes which suppressed the proliferation of immune cells but RA failed to induce $\mathrm{DC}_{\text {regs }}$. Our data suggests that RA has unique effects on different myeloid populations during differentiation that may influence the regulatory abilities of monocytes and DCs. A more thorough understanding of how RA mediates these differential effects has important implications in our understanding of $\mathrm{MC}_{\mathrm{reg}}$ biology and the potential application of these cells to treat a wide variety of inflammatory diseases.

Methods
Mice
C57BL/6 (H-2 $\left.{ }^{\text {b }}\right)$ mice (4-8 wk old), C57BL/6-Tg (TcraTcrb)
425Cbn/J, C57BL/6-Tg(Tcra2D2,Tcrb2D2)1Kuch/J and

reporter Foxp3EGFP (B6.Cg-Foxp3 $3^{\text {tm2Tch)}}$ ) were purchased from Jackson Laboratories (Bar Harbor, ME, USA) or bred in-house. Mice were housed five per cage and maintained on a $12 \mathrm{hr}$. light/dark cycle, maintained under specific pathogen-free conditions and were housed and cared for according to the institutional guidelines of the Ohio State University's Institute for Animal Care and Use Committee.

\section{Cell lines}

EG7 and EL7 (kindly provided by P. Boyaka, Ohio State University) were used to study the MHC class I-restricted response of CTLs in mice. The EG7 cells have been transfected with plasma to synthesize and constitutively secrete OVA 257-264 peptide and should be cultured in 10\% RPMI. The EL4 cells are the non-OVA secreting duplicate of the EG7. Both are commonly found at ATCC but were acquired through Dr. Boyaka. The DC2.4 cell line was kindly provided by K. Rock, University of Massachessetts and as a DC antigenpresenting cell.

\section{BM-MC differentiation and development of regulatory MC differentiation model}

Bone marrow (BM) cells were collected from $\mathrm{C} 57 \mathrm{Bl} / 6$ mice femurs and tibias. After erythrocyte lysis (AKC or inhouse lysis buffer), cells were cultured with RPMI 1640 (Invitrogen) supplemented with 10\% FBS, 25 mM HEPES, $2 \mathrm{mM}$ L-glutamine, $50 \mathrm{U} / \mathrm{ml}$ penicillin, $50 \mathrm{mg} / \mathrm{ml}$ streptomycin, $5 \times 10^{-5} \mathrm{M} 2$-mercaptoethanol and $200 \mathrm{U} / \mathrm{ml}$ recombinant murine GM-CSF (R\&D Systems) $\pm 100 \mathrm{nM}$ of either estriol (E3) or all-trans retinoic acid (RA) (SigmaAldrich) for 6-7 days at a density of $2 \times 10^{6} \mathrm{cells} / \mathrm{ml}$. Day 6-7 cells were considered differentiated BM-MCs (media control) and $\mathrm{BM}-\mathrm{MC}_{\text {regs }}(\mathrm{RA}$ and E3). Cells were challenged with inflammatory stimulus LPS $(1 \mu \mathrm{g} / \mathrm{ml}$, 055:B5, Sigma-Aldrich) during culture as indicated at day 6 or later for BM-DCs.

\section{Functional immunosuppressive assays: T cell proliferation assay}

Myeloid cells (BM-MCs or BM-MC $\mathrm{C}_{\text {regs }}$ ) were cultured with responder spleen cells from antigen-specific $\mathrm{T}$ cell receptor transgenic (TCR Tg; where antigen was either OVA323-339 or MOG35-55) or Foxp3EGFP mice as indicated. To assess $\mathrm{T}$ cell proliferation co-cultures were stimulated with anti-CD3 (BD Bioscience), T cell-receptor specific antigen MOG35-55 (Bio Matic) or T cell-receptor specific antigen OVA 323-339 (Anaspec). To assess the effects of myeloid cell activation, co-cultures were stimulated with LPS from Escherichia coli, 055:B5 (Sigma-Aldrich) for 96 hours, pulsed with ( $\mathrm{H}^{3}$ thymidine) (Perkin Elmer Life Sciences or MP Biomedicals) in the last 18 hours, harvested and counted, data is expressed as counts per million $(\mathrm{cpm}) \pm$ SEM [35]. 
Functional immunosuppressive assay: $\mathrm{CD} 8^{+}$cytotoxic assay To generate CTL, spleen and lymph nodes (LN) were removed from OT-1 mice and co-cultured with OVA (257-264) pulsed DC2.4 cells (kindly provided by Kenneth Rock, University of Massachussets) for 4 days, removed and cultured with mrIL-2 (R\&D Systems) for 2 days. OVA-expressing (EG7) and non-transfected control cells (EL4) were seeded at $2 \times 10^{4}$ cells per well and co-cultured with CTLs $\left(1 \times 10^{5}\right)$ and control or RA treated monocytes $\left(2 \times 10^{4}\right)$ for 6-18 hours [73,78]. The MTT assay (Sigma-Aldrich) was used to determine quantity of live cells. Briefly, after incubation, cells were centrifuged (1500 RPM for 5 min) media was decanted and $100 \mathrm{ul}$ of fresh media was added. $10 \mathrm{ul} \mathrm{of} 5 \mathrm{mg} / \mathrm{ml}$ thiazolyl blue tetrazolium bromide (MTT) was added to each well for 2 hours at $37^{\circ} \mathrm{C}$. After incubation cells were centrifuged (1500 RPM for $7 \mathrm{~min}$ ) and media was decanted, cells were allowed to dry for 15-30 min before $100 \mathrm{ul}$ of DMSO was added, mixed well and read at $570 \mathrm{~nm}$ on a Spectra Max 2. The absorbance levels were calculated by averaging the non-specific and specific absorbance levels of five separate data sets. Media control is compared to RA treated cells.

\section{In vitro $\mathrm{T}_{\text {reg }}$ induction}

Bone marrow (BM) cells were collected from C57Bl/6 mice femurs and tibias. After erythrocyte lysis, BM cells were cultured with supplemented RPMI (as previously described) for 7 days at a density of $2 \times 10^{6}$ cells $/ \mathrm{ml}+/-$ RA. Spleens from mice with reporter Foxp3EGFP (B6. Cg-Foxp $3^{\text {tm2Tch) }}$ ) were harvested, passed through cell strainers $(70 \mu \mathrm{m}, \mathrm{BD}$ Falcon), collected by centrifugation (1500 RPM for 7 Min at $4^{\circ} \mathrm{C}$ ) and subjected to erythrocyte lysis. Responder cells and MCs or CD11c MCs were cultured for 4-6 days and aliquots from cultures assessed for Foxp3 expression by flow cytometry.

\section{Flow cytometry}

In vivo and in vitro derived DCs and MCs were labeled and evaluated by three-color flow cytometry using combination of the following conjugated directly antibodies (clone): CD11c (HL3), CD11b (M1/70), Gr-1 (RB6-8C5), Ly-6G (1A8), Ly-6C (AL-21), MHC class II (AF6-120.1), CD80 (16-10A1), CD86 (IT 2.2), PD-L1 (MIH5), and PD-L2 (YT25) with appropriate isotype controls. (BD Bioscience, eBiosciences or Miltenyi Biotec). Cells were stained with fluorochrome-labeled antibodies or isotype controls for $20 \mathrm{~min}$ in the dark at $4^{\circ} \mathrm{C}$, washed twice in FACS buffer and re-suspended in $300 \mu$ FACS buffer for flow cytometry analysis.

Intracellular IL-10, IL-4, IL-17 and INF- $\gamma$ levels were measured after incubating myeloid cells with $1 \mu \mathrm{g} / \mathrm{ml}$ LPS overnight (IL-10) or Ionomyocin (1 mg/ml) and PMA (25 ng/ml) for 4 hours (IL-4, IL-17, and INF- $\gamma$ ).
$2 \mu \mathrm{M}$ of Monensin (eBioscience) added 2-4 hrs. before harvesting cells. Cells were removed from culture, washed with $2 \mathrm{ml}$ of supplemented RPMI and blocked with $0.5 \mu \mathrm{g} / \mathrm{ml}$ Fc block (anti-CD16/CD32) for $15 \mathrm{mi}$ nutes. Cells that required extracellular markers were re-suspended in FACS buffer and stained with antiCD4 $(0.2 \mathrm{mg} / \mathrm{ml})$ and incubated in the dark at $4^{\circ} \mathrm{C}$ for 20 min. Cells were washed with FACS buffer (2x with $1 \mathrm{ml}$ ) and then fixed and permeabilized using FIX/ PERM solution (BD Bioscience), briefly vortexed and incubated in the dark at $4^{\circ} \mathrm{C}$ for $20 \mathrm{~min}$. Cells were then washed twice with $1 \mathrm{ml}$ of PERM/WASH buffer (BD Bioscience), re-suspended in PERM/WASH buffer and stained with $0.2 \mathrm{mg} / \mathrm{ml}$ anti-IL-10 (BD Bioscience) for $30 \mathrm{~min}$. in the dark at $4^{\circ} \mathrm{C}$. All flow samples were processed on an Accuri C6 flow cytometer and results analyzed using the Accuri C6 Flow software (BD Biosciences).

\section{Myeloid cell purification}

Day 6-7 differentiated BM cells were incubated with manufacturer suggested amounts of CD11c/CD11b microbeads (Miltenyi Biotec) for 15 minutes in the dark at $4^{\circ} \mathrm{C}$. Cells were washed with running buffer (10\% FBS in PBS with $900 \mathrm{mg}$ of $\mathrm{NaN}_{2}$ per $1 \mathrm{~L}$ of PBS), and centrifuged (1500 RPM, 7Min). Cell separation was performed using either the Auto Macs (Miltenyi Biotec) magnetic separation instrument or the FACS Aria III 12 color, 4 laser cell sorter. The Auto Macs was used according to the manufacturer's instructions. Cell sorting with the FACS Aria III was performed at the OSU Flow Cytometry Core and isotype control antibodies were included to determine detection levels. CD $11 b^{+}$CD $11 c^{-}$Ly-6C $C^{\text {low }}$ monocyte populations were serially gated on $\mathrm{CD}_{11 \mathrm{c}^{-}}$ cells, followed by $\mathrm{CD}_{1} 1 \mathrm{~b}^{+}$with gates set around distinct populations of Ly-6C low, intermediate and high. The purity of the cell populations was $\geq 95 \%$.

\section{Statistical analysis}

Data are represented as mean $+/$ - SEM or fold change. Statistical significance was determined using a Student's t-test or 1 way ANOVA with a significance level (pvalue) $<0.05$ and the Wilcoxen signed-rank test. All analyses were performed using Excel and/or GraphPad Prism software (La Jolla, CA).

\section{Additional files}

Additional file 1: Figure S1. GM-CSF induced myeloid cells. BM-MCs were differentiated for 6-7 days and characterized phenotypically using the Accuri C6 Flow cytometer to identify the relative percentage of the cell population expressing (A) of CD11 $\mathrm{c}^{+}$and $\mathrm{CD} 11 \mathrm{~b}^{+}$media and RA differentiated cells. Expression of LY-6G was evaluated by the Accuri C6 cytometer of the (B) CD11 b cells. Data are representative of at least three separate experiments. 
Additional file 2: Figure S2. $C D 11 C^{-} \mid L-10$ and $T_{\text {reg }}$ cell induction. Bone marrow cells were differentiated in the presence of GM-CSF with or without $100 \mathrm{nM}$ of or retinoic acid over 7 days to generate BM-MCs. Following differentiation MCs were magnetically labeled with $\mathrm{CD} 11 \mathrm{c}^{+}$beads and separated with the AutoMacs. Purity was confirmed by routine staining of positive and negative cells with FITC-conjugated anti-CD11C antibody and cells were run on the Accuri C6 Flow cytometer. (A) The relative percentage of $\mathrm{IL}-10^{+}$cells was determined in control MCs and RA MC regs Data are representative of at least three separate experiments. (B) Day 7 media CD $11 b^{+}$CD11 $c^{-}$MCs or RA CD11 b $b^{+}$CD11c-MCs were co-cultured in the presence of Foxp3EGFP reporter cells and expression of Foxp3 $3^{+}$cells was evaluated in the lymphocyte population over time in the cultures by flow cytometry. Data shown is a representation of 3 experiments.

\section{Abbreviations}

APC: Antigen presenting cell; GM-CSF: Granulocyte-macrophage colonystimulating factor; PD-L1: PD-L2, Program death ligand 1 and 2; E3: Estriol; DC: Dendritic cell; tDC/DC reg: Tolerogenic/Regulatory Dendritic cell.

\section{Competing interests}

The authors declare that they have no competing of interest.

\section{Authors' contributions}

ZCV, JDB, DCM, HRS, MG-d-A and TLP performed research and analyzed data. TLP designed the research. SO-M provided statistical data analysis. ZCV and TLP wrote the manuscript. TLP and HRS revised and edited the manuscript. All authors read and approved the final manuscript.

\section{Acknowledgements}

This work was supported by the National Institutes of Health (K01RR022198 and R21 Al095773-01A1) and the Department of Veterinary Biosciences, College of Veterinary Medicine. The authors thank Drs. Caroline Whitacre, Prosper Boyaka and Kenneth Rock for providing the FoxP3 ${ }^{+}$EGFP, EG7/EL4 and DC2.4 cell lines, respectively. The authors thank Dr. Blake Eason Hildreth III for his contributions to statistical analysis and Drs. Prosper Boyaka and Junbae Jee for their intellectual discussions. The authors would like to acknowledge the Analytical Cytometry Shared Resource at the OSUCCC-James for all flow sorting.

\section{Author details}

${ }^{1}$ Department of Veterinary Biosciences, The Ohio State University, College of Veterinary Medicine, 370 Veterinary Medical Academic Building, 1900 Coffey Road, Columbus, OH 43210, USA. Division of Medical Laboratory Science, School of Health and Rehabilitation Sciences, School of Health and Rehabilitation Science, The Ohio State University, Columbus, OH 43210, USA. ${ }^{3}$ Division of Epidemiology, College of Public Health, The Ohio State University, Columbus, $\mathrm{OH}$ 43210, USA.

\section{Received: 18 July 2013 Accepted: 6 January 2014}

Published: 18 February 2014

\section{References}

1. Geissmann F, Manz MG, Jung S, Sieweke MH, Merad M, Ley K: Development of monocytes, macrophages, and dendritic cells. Science (New York, NY) 2010, 327:656-661.

2. Steinman RM, Hawiger D, Nussenzweig MC: Tolerogenic dendritic cells. Annu Rev Immunol 2003, 21:685-711.

3. Gabrilovich DI, Velders MP, Sotomayor EM, Kast WM: Mechanism of immune dysfunction in cancer mediated by immature Gr-1+ myeloid cells. J Immuno/ 2001, 166:5398-5406.

4. Martinez FO, Helming L, Gordon S: Alternative activation of macrophages: an immunologic functional perspective. Annu Rev Immunol 2009, 27:451-483

5. Gordon S, Taylor PR: Monocyte and macrophage heterogeneity. Nat Rev Immunol 2005, 5:953-964.

6. Manicassamy S, Pulendran B: Dendritic cell control of tolerogenic responses. Immunological reviews 2011, 241:206-227.

7. Geissmann F, Auffray C, Palframan R, Wirrig C, Ciocca A, Campisi L, NarniMancinelli E, Lauvau G: Blood monocytes: distinct subsets, how they relate to dendritic cells, and their possible roles in the regulation of T-cell responses. Immunology and cell biology 2008, 86:398-408.

8. Yokota A, Takeuchi H, Maeda N, Ohoka Y, Kato C, Song SY, Iwata M: GMCSF and IL-4 synergistically trigger dendritic cells to acquire retinoic acid-producing capacity. International immunology 2009, 21:361-377.

9. Guilliams M, Crozat K, Henri S, Tamoutounour S, Grenot P, Devilard E, de Bovis B, Alexopoulou L, Dalod M, Malissen B: Skin-draining lymph nodes contain dermis-derived CD103(-) dendritic cells that constitutively produce retinoic acid and induce Foxp3(+) regulatory T cells. Blood 2010, 115:1958-1968.

10. Fontenot JD, Gavin MA, Rudensky AY: Foxp3 programs the development and function of CD4 + CD25+ regulatory T cells. Nat immunol 2003, 4:330-336.

11. Gavin MA, Rasmussen JP, Fontenot JD, Vasta V, Manganiello VC, Beavo JA, Rudensky AY: Foxp3-dependent programme of regulatory T-cell differentiation. Nature 2007, 445:771-775.

12. Hori S, Nomura T, Sakaguchi S: Control of regulatory T cell development by the transcription factor Foxp3. Science (New York, NY) 2003, 299:1057-1061.

13. Gershon RK, Cohen P, Hencin R, Liebhaber SA: Suppressor T cells. $\mathrm{J}$ Immuno/ 1972, 108:586-590.

14. Harry RA, Anderson AE, Isaacs JD, Hilkens CM: Generation and characterisation of therapeutic tolerogenic dendritic cells for rheumatoid arthritis. Ann Rheum Dis 2010, 69:2042-2050.

15. Giannoukakis N, Phillips B, Finegold D, Harnaha J, Trucco M: Phase I (safety) study of autologous tolerogenic dendritic cells in type 1 diabetic patients. Diabetes care 2011, 34:2026-2032.

16. Geissler EK: The ONE Study compares cell therapy products in organ transplantation: introduction to a review series on suppressive monocyte-derived cells. Transplantation research 2012, 1:11.

17. Yin B, Ma G, Yen CY, Zhou Z, Wang GX, Divino CM, Casares S, Chen SH, Yang WC, Pan PY: Myeloid-derived suppressor cells prevent type 1 diabetes in murine models. J Immunol 2010, 185:5828-5834.

18. Wada $Y$, Hisamatsu T, Kamada N, Okamoto S, Hibi T: Retinoic acid contributes to the induction of IL-12-hypoproducing dendritic cells. Inflamm Bowel Dis 2009, 15:1548-1556.

19. Soroosh P, Doherty TA, Duan W, Mehta AK, Choi H, Adams YF, Mikulski Z, Khorram N, Rosenthal P, Broide DH, Croft M: Lung-resident tissue macrophages generate Foxp3+ regulatory $T$ cells and promote airway tolerance. J Exp Med 2013, 210:775-788.

20. Weber MS, Prod'homme T, Youssef S, Dunn SE, Rundle CD, Lee L, Patarroyo JC, Stuve O, Sobel RA, Steinman L, Zamvil SS: Type II monocytes modulate T cell-mediated central nervous system autoimmune disease. Nature medicine 2007, 13:935-943.

21. Kavousanaki M, Makrigiannakis A, Boumpas D, Verginis P: Novel role of plasmacytoid dendritic cells in humans: induction of interleukin-10 producing Treg cells by plasmacytoid dendritic cells in patients with rheumatoid arthritis responding to therapy. Arthritis Rheum 2010, 62:53-63.

22. Anderson AE, Sayers BL, Haniffa MA, Swan DJ, Diboll J, Wang XN, Isaacs JD, Hilkens CM: Differential regulation of naive and memory CD4+ T cells by alternatively activated dendritic cells. Journal of leukocyte biology 2008, 84:124-133.

23. Thomson AW, Robbins PD: Tolerogenic dendritic cells for autoimmune disease and transplantation. Annals of the rheumatic diseases 2008 , 67(Suppl 3):iii90-96.

24. Dong X, Bachman LA, Kumar R, Griffin MD: Generation of antigen-specific, interleukin-10-producing T-cells using dendritic cell stimulation and steroid hormone conditioning. Transpl Immunol 2003, 11:323-333.

25. Steinbrink K, Wolfl M, Jonuleit $H$, Knop J, Enk AH: Induction of tolerance by IL-10-treated dendritic cells. J Immunol 1997, 159:4772-4780.

26. Vieira PL, Kalinski $P$, Wierenga EA, Kapsenberg ML, de Jong EC Glucocorticoids inhibit bioactive IL-12p70 production by in vitro-generated human dendritic cells without affecting their T cell stimulatory potential. J Immunol 1998, 161:5245-5251.

27. Adorini L, Giarratana N, Penna G: Pharmacological induction of tolerogenic dendritic cells and regulatory T cells. Semin Immunol 2004, 16:127-134.

28. Hackstein $H$, Thomson AW: Dendritic cells: emerging pharmacological targets of immunosuppressive drugs. Nat Rev Immunol 2004, 4:24-34. 
29. Kodaira Y, Nair SK, Wrenshall LE, Gilboa E, Platt JL: Phenotypic and functional maturation of dendritic cells mediated by heparan sulfate. J Immunol 2000, 165:1599-1604.

30. Bros M, Jahrling F, Renzing A, Wiechmann N, Dang NA, Sutter A, Ross R, Knop J, Sudowe S, Reske-Kunz AB: A newly established murine immature dendritic cell line can be differentiated into a mature state, but exerts tolerogenic function upon maturation in the presence of glucocorticoid. Blood 2007, 109:3820-3829.

31. Steinman RM, Banchereau J: Taking dendritic cells into medicine. Nature 2007, 449:419-426.

32. Lan YY, Wang Z, Raimondi G, Wu W, Colvin BL, de Creus A, Thomson AW: "Alternatively activated" dendritic cells preferentially secrete IL-10, expand Foxp3 + CD4+ T cells, and induce long-term organ allograft survival in combination with CTLA4-lg. J Immunol 2006, 177:5868-5877.

33. Anderson AE, Swan DJ, Sayers BL, Harry RA, Patterson AM, von Delwig A, Robinson JH, Isaacs JD, Hilkens CM: LPS activation is required for migratory activity and antigen presentation by tolerogenic dendritic cells. J Leukoc Biol 2009, 85:243-250.

34. Voigtlander C, Rossner S, Cierpka E, Theiner G, Wiethe C, Menges M, Schuler G, Lutz MB: Dendritic cells matured with TNF can be further activated in vitro and after subcutaneous injection in vivo which converts their tolerogenicity into immunogenicity. Journal of immunotherapy (Hagerstown, Md: 1997) 2006, 29:407-415.

35. Papenfuss TL, Powell ND, McClain MA, Bedarf A, Singh A, Gienapp IE, Shawler T, Whitacre CC: Estriol generates tolerogenic dendritic cells in vivo that protect against autoimmunity. J Immunol 2011, 186:3346-3355.

36. Manicassamy S, Pulendran B: Retinoic acid-dependent regulation of immune responses by dendritic cells and macrophages. Semin Immunol 2009, 21:22-27.

37. Pulendran $B$, Tang $H$, Manicassamy S: Programming dendritic cells to induce $\mathrm{T}(\mathrm{H}) 2$ and tolerogenic responses. Nature immunology 2010 , 11:647-655.

38. Duester G: Retinoic acid synthesis and signaling during early organogenesis. Cell 2008, 134:921-931.

39. Strober W: Vitamin A rewrites the ABCs of oral tolerance. Mucosal immunol 2008, 1:92-95.

40. Cassani B, Villablanca EJ, De Calisto J, Wang S, Mora JR: Vitamin A and immune regulation: role of retinoic acid in gut-associated dendritic cell education, immune protection and tolerance. Mol Aspects Med 2012, 33:63-76.

41. Feng $\mathrm{T}$, Cong Y, Qin H, Benveniste EN, Elson CO: Generation of mucosal dendritic cells from bone marrow reveals a critical role of retinoic acid. J Immunol 2010, 185:5915-5925.

42. Lutz MB, Suri RM, Niimi M, Ogilvie AL, Kukutsch NA, Rossner S, Schuler G, Austyn JM: Immature dendritic cells generated with low doses of GM-CSF in the absence of IL-4 are maturation resistant and prolong allograft survival in vivo. Eur J Immunol 2000, 30:1813-1822.

43. Saurer L, McCullough KC, Summerfield A: In vitro induction of mucosatype dendritic cells by all-trans retinoic acid. J immunol 2007, 179:3504-3514.

44. Kusmartsev S, Cheng F, Yu B, Nefedova Y, Sotomayor E, Lush R, Gabrilovich D: All-trans-retinoic acid eliminates immature myeloid cells from tumorbearing mice and improves the effect of vaccination. Cancer Res 2003, 63:4441-4449.

45. Geissmann F, Revy P, Brousse N, Lepelletier Y, Folli C, Durandy A, Chambon $P$, Dy M: Retinoids regulate survival and antigen presentation by immature dendritic cells. J Exp Med 2003, 198:623-634.

46. Szatmari I, Nagy L: Nuclear receptor signalling in dendritic cells connects lipids, the genome and immune function. The EMBO journal 2008, 27:2353-2362

47. Kim $\mathrm{CH}$ : Roles of retinoic acid in induction of immunity and immune tolerance. Endocr Metab Immune Disord Drug Targets 2008, 8:289-294.

48. Huang ME, Ye YC, Chen SR, Chai JR, Lu JX, Zhao L, Gu LJ, Wang ZY: Use of all-trans retinoic acid in the treatment of acute promyelocytic leukemia. Haematol Blood Transfus 1989, 32:88-96.

49. Mi JQ, Li JM, Shen ZX, Chen SJ, Chen Z: How to manage acute promyelocytic leukemia. Leukemia 2012, 26:1743-1751.

50. Ostrand-Rosenberg S: Myeloid-derived suppressor cells: more mechanisms for inhibiting antitumor immunity. Cancer Immunol Immunother 2010, 59:1593-1600.
51. Ostrand-Rosenberg S, Sinha P: Myeloid-derived suppressor cells: linking inflammation and cancer. J Immuno/ 2009, 182:4499-4506.

52. Drumea K, Yang ZF, Rosmarin A: Retinoic acid signaling in myelopoiesis. Curr Opin Hematol 2008, 15:37-41.

53. Mirza N, Fishman M, Fricke I, Dunn M, Neuger AM, Frost TJ, Lush RM, Antonia S, Gabrilovich DI: All-trans-retinoic acid improves differentiation of myeloid cells and immune response in cancer patients. Cancer research 2006, 66:9299-9307.

54. Rosas M, Osorio F, Robinson MJ, Davies LC, Dierkes N, Jones SA, Reis e Sousa C, Taylor PR: Hoxb8 conditionally immortalised macrophage lines model inflammatory monocytic cells with important similarity to dendritic cells. Eur J Immunol 2011, 41:356-365.

55. Skrzeczynska-Moncznik J, Bzowska M, Loseke S, Grage-Griebenow E, Zembala M, Pryjma J: Peripheral blood CD14high CD16+ monocytes are main producers of IL-10. Scand J Immunol 2008, 67:152-159.

56. Lutz MB, Kukutsch N, Ogilvie AL, Rossner S, Koch F, Romani N, Schuler G: An advanced culture method for generating large quantities of highly pure dendritic cells from mouse bone marrow. J Immunol Methods 1999, 223:77-92.

57. Zeng R, Oderup C, Yuan R, Lee M, Habtezion A, Hadeiba H, Butcher EC Retinoic acid regulates the development of a gut-homing precursor for intestinal dendritic cells. Mucosal immunology 2012, 6:847-856.

58. Inaba K, Inaba M, Romani N, Aya H, Deguchi M, Ikehara S, Muramatsu S, Steinman RM: Generation of large numbers of dendritic cells from mouse bone marrow cultures supplemented with granulocyte/macrophage colony-stimulating factor. J Exp Med 1992, 176:1693-1702.

59. van de Laar L, Coffer PJ, Woltman AM: Regulation of dendritic cell development by GM-CSF: molecular control and implications for immune homeostasis and therapy. Blood 2012, 119:3383-3393.

60. Hengesbach LM, Hoag KA: Physiological concentrations of retinoic acid favor myeloid dendritic cell development over granulocyte development in cultures of bone marrow cells from mice. J Nutr 2004, 134:2653-2659.

61. Athens JW, Haab OP, Raab SO, Mauer AM, Ashenbrucker H, Cartwright GE, Wintrobe MM: Leukokinetic studies. IV. The total blood, circulating and marginal granulocyte pools and the granulocyte turnover rate in normal subjects. J Clin Invest 1961, 40:989-995.

62. Suratt BT, Young SK, Lieber J, Nick JA, Henson PM, Worthen GS: Neutrophil maturation and activation determine anatomic site of clearance from circulation. Am J Physiol Lung Cell Mol Physiol 2001, 281:L913-921.

63. Sunderkotter C, Nikolic T, Dillon MJ, Van Rooijen N, Stehling M, Drevets DA, Leenen PJ: Subpopulations of mouse blood monocytes differ in maturation stage and inflammatory response. J Immunol 2004, 172:4410-4417.

64. Penna G, Adorini L: 1 Alpha,25-dihydroxyvitamin D3 inhibits differentiation, maturation, activation, and survival of dendritic cells leading to impaired alloreactive T cell activation. J Immunol 2000, 164:2405-2411.

65. Emmer PM, van der Vlag J, Adema GJ, Hilbrands LB: Dendritic cells activated by lipopolysaccharide after dexamethasone treatment induce donor-specific allograft hyporesponsiveness. Transplantation 2006, 81:1451-1459.

66. Fujihara M, Muroi M, Tanamoto K, Suzuki T, Azuma H, Ikeda H: Molecular mechanisms of macrophage activation and deactivation by lipopolysaccharide: roles of the receptor complex. Pharmacology \& therapeutics 2003, 100:171-194.

67. Sun CM, Hall JA, Blank RB, Bouladoux N, Oukka M, Mora JR, Belkaid Y: Small intestine lamina propria dendritic cells promote de novo generation of Foxp3 T reg cells via retinoic acid. J Exp Med 2007, 204:1775-1785.

68. Belkaid $Y$, Oldenhove G: Tuning microenvironments: induction of regulatory T cells by dendritic cells. Immunity 2008, 29:362-371.

69. McClain MA, Gatson NN, Powell ND, Papenfuss TL, Gienapp IE, Song F, Shawler TM, Kithcart A, Whitacre CC: Pregnancy suppresses experimental autoimmune encephalomyelitis through immunoregulatory cytokine production. J Immunol 2007, 179:8146-8152.

70. Ardavin C: Origin, precursors and differentiation of mouse dendritic cells. Nat Rev Immunol 2003, 3:582-590.

71. Varol C, Landsman L, Fogg DK, Greenshtein L, Gildor B, Margalit R, Kalchenko V, Geissmann F, Jung S: Monocytes give rise to mucosal, but not splenic, conventional dendritic cells. J Exp Med 2007, 204:171-180. 
72. del Hoyo GM, Martin P, Vargas HH, Ruiz S, Arias CF, Ardavin C:

Characterization of a common precursor population for dendritic cells. Nature 2002, 415:1043-1047.

73. Sutherland AP, Joller N, Michaud M, Liu SM, Kuchroo VK, Grusby MJ: IL-21 promotes CD8+ CTL activity via the transcription factor T-bet. I Immunol 2013, 190:3977-3984.

74. Auffray C, Sieweke MH, Geissmann F: Blood monocytes: development, heterogeneity, and relationship with dendritic cells. Annu Rev Immunol 2009, 27:669-692.

75. Nahrendorf M, Swirski FK, Aikawa E, Stangenberg L, Wurdinger T, Figueiredo JL, Libby P, Weissleder R, Pittet MJ: The healing myocardium sequentially mobilizes two monocyte subsets with divergent and complementary functions. J Exp Med 2007, 204:3037-3047.

76. Schiopu A, Nadig SN, Cotoi OS, Hester J, van Rooijen N, Wood KJ: Inflammatory Ly-6C(hi) monocytes play an important role in the development of severe transplant arteriosclerosis in hyperlipidemic recipients. Atherosclerosis 2012, 223:291-298

77. Ziegler-Heitbrock L, Ancuta P, Crowe S, Dalod M, Grau V, Hart DN, Leenen PJ, Liu YJ, MacPherson G, Randolph GJ, Scherberich J, Schmitz J, Shortman K, Sozzani S, Strobl H, Zembala M, Austyn JM, Lutz MB: Nomenclature of monocytes and dendritic cells in blood. Blood 2010, 116:e74-80.

78. Robinson MJ, Ronchese F, Miller JH, La Flamme AC: Paclitaxel inhibits killing by murine cytotoxic T lymphocytes in vivo but not in vitro. Immunology and cell biology 2010, 88:291-296.

doi:10.1186/1471-2172-15-8

Cite this article as: VanGundy et al:: Continuous retinoic acid induces the differentiation of mature regulatory monocytes but fails to induce regulatory dendritic cells. BMC Immunology 2014 15:8.

\section{Submit your next manuscript to BioMed Central and take full advantage of:}

- Convenient online submission

- Thorough peer review

- No space constraints or color figure charges

- Immediate publication on acceptance

- Inclusion in PubMed, CAS, Scopus and Google Scholar

- Research which is freely available for redistribution 